The Geneva Papers on Risk and Insurance, 15 (No. 57, October 1990), 407-427

\title{
Insurance Perspectives on an Integrated Hazardous Waste Management Strategy*
}

\author{
by Neil Doherty**, Paul Kleindorfer** and Howard Kunreuther ${ }^{* *}$
}

\section{The nature of the insurability problem}

The generation, transport, storage, and disposal of hazardous wastes all entail significant risks. Policy makers in government and industry typically foresee important roles for insurance as a prudent instrument for mitigating these risks and for assuring appropriate compensation in the event of damage. Policy makers and others differ in their views as to what role insurance might properly play in an integrated waste management strategy. This paper is concerned with analyzing this issue from both a theoretical and an institutional perspective.

Insurance may be defined as a mechanism for pooling the risky exposures of a number of individuals or firms. The risky exposures define the prospects for financial loss facing each individual or firm and the pooling process permits the risk facing each to be reduced or removed through a process of diversification. Insurance markets have arisen on a voluntary basis to cover many types of exposure; common examples are fire; weather related damage; operation of automobiles and other means of transport; common law liabilities for malpractice, defective products, ownership of property etc.; and loss of life or health.

The essential feature of such voluntary markets is that they offer both parties some advantage from trading. From the individual's viewpoint, insurance reduces risk, enabling him to face a more predictable financial future. Similarly the firm will benefit from risk sharing, thus permitting longer range planning and a less costly operation. Owners of the insurance company are offered an expected return on their investment that compensates them for putting their capital at risk. A healthy insurance market requires such mutual gain.

Some insurance markets in the United States, such as homeowners, automobile and life, do appear to function effectively with minimal intervention from state regulators. Other markets are more troublesome and sometimes disappear altogether. A recent example is the limited interest by the insurance industry in marketing earthquake insurance in areas of vigorous seismic activity. Recent proposals have the federal government serve

* Special thanks to Rajeev Gowda for his assistance in preparing this paper. We benefitted greatly from discussions with Leslie Cheek, David Havanich and John Morrison.

** Risk and Decision Processes Center, The Wharton School, Philadelphia. 
as the principal bearer of the risk of catastrophic losses. Another example is the medical malpractice insurance market that has suffered a sequence of crises in the 1970's and 1980's. Additionally, the U.S. commercial liability insurance market as a whole appeared to be in a state of crisis in the mid-1980's.

No market has been more troubled recently than the market for environmental impairment liability insurance (EIL). Coinciding with the general liability insurance crisis, a sequence of mammoth and controversial court awards, and recent Congressional legislation related to potential liability from operating or cleaning-up of facilities, the pollution insurance markets have all but disappeared. And this despite the fact that major legislation had defined a clear financial responsibility role for the insurance sector as part of a social policy for managing environmental impairment risk.

The pathology of insurance markets may be addressed by identifying the conditions under which they do function efficiently. Such conditions have been described as the "preconditions for insurability". The expression "preconditions" is strong since insurance markets do exist and flourish even if all the stated conditions are not met. However, serious breach of several conditions can lead to stress in the insurance market and in some cases such as EIL may lead to only a trickle of available coverage. The conditions for insurability are widely discussed in most insurance textbooks and were recently formalized (from an actuary's viewpoint) in a book by Baruch Berliner [1982]. These conditions provide a basis for discussing feasible and appropriate roles for insurance in hazardous waste management and serve as the foundation for our discussion of insurance in an integrated waste management strategy.

Our paper will proceed as follows: First, we discuss recent legislative, judicial and regulatory developments in the environmental area. We then outline the general "preconditions for insurability". We then generalize this discussion by developing an insurability grid to classify current insurability problems in hazardous waste management. Against this backdrop of insurability, we discuss the central role of insurance in an integrated waste management strategy. A set of alternatives for correcting the current problems in EIL insurance markets in this area are offered in conclusion.

\section{Insurance implications of environmental legislation}

Social concern for the consequences of environmental pollution is reflected in recent legislation and in the decisions of the courts. If judicial decisions provide a barometer of social values, then the recent relaxations of conditions for a successful court suit and the increase in the size of awards is compatible with an increased social emphasis on compensating those affected by toxic waste and, arguably, in deterring or curtailing activities which generate these wastes. But a more direct expression of social concerns lies in legislation. The main issues can be illustrated by two important recent Congressional enactments : the Resource Conservation and Recovery Act (RCRA) of 1976 and the Comprehensive Environmental Response, Compensation and Liability Act (CERCLA) of 1980.

RCRA has been described as a "cradle to grave" approach to the regulation of hazardous waste substances. It focuses on the treatment, storage and disposal of hazardous materials requiring (amongst other things) that owners and operators keep adequate records and show financial responsibility for the operation and closure of sites and post- 
closure care of sites extending to a period of 30 years after closure. ${ }^{1}$ A principal means of satisfying the financial responsibility requirements is the demonstration of adequate insurance protection.

In contrast, the emphasis in CERCLA has been on the cleanup of existing sites that have been deemed to pose serious public health problems. While this Act provides some funding for cleanup activities, it nevertheless imposes liability for such cleanup costs on "responsible parties". Courts have consistently held that CERCLA imposes strict liability, meaning that the governments need not prove negligence, or failure to exercise due care, in order for defendants to be liable for cleanup costs (see GAO, [1987]). Judicial decisions have also imposed "joint and several" liability on responsible parties. The recent amendments to CERCLA, the Superfund Amendments and Reauthorization Act of 1986 (SARA), continues to maintain the existing structure of liabilities. However, under SARA, cleanup contractors are indemnified if they are unable to obtain adequate insurance in the market.

These legislative enactments reflect a joint concern that hazardous materials be controlled, that severely hazardous sites be abated and that victims be compensated for damages. In the debate surrounding these enactments a set of implicit roles for achieving these ends have evolved. Some of these roles have generated considerable controversy:

2.1. Insurers will act as policemen, monitoring the activities of those who generate, transport and dispose of hazardous materials. The policeman role encompasses the monitoring of activities, measuring the degree of risk and the provision of incentives to abate the risk. The monitoring and measurement activities may potentially be achieved through a combination of risk assessment and actuarial assessment; the former concentrating on engineering tools to measure risk and the latter concentrating on statistical methods. Of course, monitoring and measuring risk is insufficient to influence behavior. Insurers also have incentives at their disposal. Poor risks can be denied insurance, may have restrictive conditions imposed on their coverage or may be subject to higher premiums. Such incentives potentially can induce economically efficient decision making with respect to the generation and disposal of toxic materials.

2.2. Insurers will act as regulators, setting standards for the generation, storage and disposal of hazardous materials. This role (see Abraham, [1982]) is much more extensive than the somewhat passive role of policeman described above. Under the regulatory role, the insurance industry could use its facilities for risk assessment, pricing and underwriting to determine and enforce acceptable standards of generation, storage and disposal. This role for insurance seems to have been assumed by default. One theory of financial responsibility envisages a partnership between government and the private sector (see Cheek, [1982]). Government sets appropriate standards of safety and protection while insurers, protected by the imposition of those standards, could underwrite third party liability

1 RCRA third-party liability requirements for Treatment, Storage, and Disposal Facilities (TSDFs) are coverage against "sudden and accidental" occurrences of $\$ 1$ million per occurrence with an annual aggregate of at least $\$ 2$ million, exclusive of legal defense costs. Similarly, land disposal facilities must have coverage against "gradual accidental occurrences" of at least $\$ 3$ million per occurrence with an annual aggregate of at least $\$ 6$ million. See United States General Accounting Office, Hazardous Waste: Issues Surrounding Insurance Availability, October 1987. Similar requirements for facilities within CERCLA's purview are being developed by the Environmental Protection Agency. 
assumed by the regulated operators. At issue is whether the EPA has fully assumed the regulatory powers granted under RCRA and CERCLA, or whether it has passed this mantle to the insurance industry.

2.3. Insurance will act as a risk spreading mechanism. The costs of toxic accidents may be large, perhaps catastrophic on those who bear them. For example, individuals and their families affected by toxic accidents may be financially devastated if they are not compensated for their injuries or losses. But compensation may cause financial ruin to the firm(s) deemed liable to pay for the costs of an accident. Through insurance, the financial impact of accidents is spread over all parties involved in the generation and disposal of toxic materials. Insofar as insurance premiums are passed on to consumers through price increases or to the Internal Revenue Service through tax deductions, the costs of accidents are spread even further over the consumer base and over the tax base.

2.4. Insurers will act as guarantors of financial responsibility should those who are deemed to be liable for damages have insufficient resources to pay for compensation or cleanup. It is in the nature of toxic accidents that the potential costs may exceed the net worth of those held liable or may only become apparent after the responsible firms cease to exist. Small firms controlling highly toxic substances have the potential for creating damages amounting to countless billions of dollars. Limited liability and bankruptcy laws jointly permit firms to cap their liabilities and thereby leave the residual costs of severe accidents with their victims. While insurers are controlled by similar corporate laws, it is envisaged that their financial capacity is somewhat greater than that of many of their policyholders.

2.5. Insurers may be viewed as a "deep pocket". This potential role is highly controversial and is unrelated to the risk spreading role. The risk spreading role envisions a passive role for insurance. By appropriate pricing, the accidents of the few are spread over the premiums of the many, with the expected losses covered by premiums. Thus the role of the equityholders of the insurance firms is to use their capital to cover any random mismatch between aggregate premiums and losses. With risk spreading there is no (ex ante) subsidy between equityholders and other stakeholders.

But the "deep pocket" role is confiscatory insofar as it envisions (ex ante) subsidies from insurance stockholders to outsiders. Such a subsidy appears to be implicit in the retroactive, and potentially unlimited, nature of the liabilities imposed under CERCLA since the policies on which these liabilities might fall could never been priced to anticipate this risk.

2.6. A final role for insurance is the economic role as a free-standing capitalist institution creating value. This role envisages insurance as an interlinking set of contracts voluntarily entered into by capital providers and those interested in risk spreading through insurance. The various parties to this arrangement expect fair economic returns (investors) or service (policyholders). Their expectations are based on a presumption of reasonable stability in the laws and regulations governing commercial activity in general and insurance in particular.

While some combination of these roles appears to be implied by social policy, it does not follow that a voluntary insurance industry will or can participate. Indeed, we will argue in the next section that toxic torts and the liabilities imposed through legislation, perform very poorly against the criteria for insurability. These problems of insurability are partly 
technological and partly judicial in nature. But the problems have been severely aggravated by the federal legislation on operating and cleaning up facilities. Indeed the legislative initiative to co-opt the insurance industry into a social policy for hazardous waste management has probably been self defeating. It was predictable that the insurance industry would opt out of its policy role in managing hazardous materials as soon as this role was thrust upon it.

\section{Insurability criteria and environmental pollution}

We shall now examine the general criteria for insurability of risks and analyze their performance in the context of environmental pollution. Appendix A applies these criteria to a hypothetical scenario involving a chemical firm and an insurance company. A more detailed discussion appears in Kunreuther [1987].

\subsection{Uncertainty}

Insurance policies attempt to limit coverage to events that are unintended and uncertain. Traditionally insurance has been viewed by the buyer as the demand for certainty. Thus highly uncertain events tend to generate a demand for insurance whereas events that are quite likely do not. An insurer will not provide coverage to firms who face a certain loss over the next year except at a premium that approaches the magnitude of the loss itself.

In the case of insuring against environmental pollution liabilities, judicial decisions and environmental legislation have caused certain risks to be uninsurable according to this criterion. Specifically the insurance industry feels that cleanup costs for unsafe waste disposal sites are uninsurable because the damages have already occurred.

Insurance policies attempt to limit cover to events that are unintended and uncertain. Thus they exclude coverage for all pollution incidents that are not "sudden and accidental". However, some courts have interpreted this clause to cover gradual pollution incidents, stating that the damages which occurred were "unintended and unexpected" from the standpoint of the insured. ${ }^{2}$

\subsection{Low correlation}

The possibility of a catastrophic loss may make a risk uninsurable. The successful pooling of risks, which is the basis of an insurer's activity, requires a low correlation between the individual exposures. The higher the average correlation between exposures, the greater the chances that claims will exceed reserves from the insurance pool due to a catastrophic loss. Such financial stress can be avoided when the risks covered by the insurer are independent of each other.

Environmental risks are not highly correlated at one point in time. However, the effects of legal developments and judicial interpretations are felt across the system and affect all insurance contracts. Insurance contracts are written at a given time under a particular regime of liability rules and contract interpretations. Changes induced by legislation

2 See Waste Management of the Carolinas Inc. v. Peerless Insurance Company (323 S. E. 2 d 726 [1984]), and Jackson Township Municipal Authority v. Hartford Accident and Indemnity Company (451 A.2d 990, 1986 [1982]). 
or adjudication simultaneously change the probability of a claim for all contracts. If legislative or judicial changes could be correctly anticipated at the time contracts are written, the impending changes could be included in the premium calculations.

For example, the introduction of joint and several liability by courts in their interpretation of CERCLA, introduced a new liability retroactively for all companies involved in the various stages of the waste lifecycle. ${ }^{3}$ This problem could conceivably arise even in the case of an existing facility if there are leaks from these facilities that cause damage. Then these facilities might be closed and treated under the auspices of CERCLA, thus providing scope for the imposition of joint and several liability.

\subsection{Identification of losses}

Losses must be well-defined as to time and place. In order for contracts to be effective, it must be possible to determine when and where such losses occurred. Problems of identifiability for environmental risks are well-known. First, the long latency periods for the development and recognition of damages are clear. A landfill may leach for many years before identifiable effects are noticed. If the firm liable for the landfill had several insurers during this period, severe identification problems arise. The introduction of joint and several liability by courts in their interpretation of CERCLA, introduces a new liability for all companies involved in the various stages of the waste lifecycle.

Second, court decisions have clouded the issue of identifiability of losses. For example, courts have redefined the meaning of the term occurrence. In the now famous Jackson Township case,$^{4}$ the alleged negligence of the landfill operators resulted in the pollutants seeping into an underground aquifer with resulting contamination to 97 privately-owned wells. In this case, the court decided that the contamination of 97 wells resulted in 97 different pollution occurrences and proceeded to apply the coverage accordingly.

Third, in the Jackson Township case the court went on to award damages for nonpecuniary losses. A total of $\$ 15.9$ million (reduced on appeal to $\$ 5.4$ million) was awarded for emotional distress, impact on quality of life, and cost of medical surveillance, to the plaintiffs who were victims of pollution.

\subsection{Estimating the probability of loss}

Ideally, for the sound financial operation of insurance, the probability distribution of future losses should be capable of accurate measurement. If insurers are ambiguous as to the chances of certain events occurring they will want to charge higher premiums for coverage. (Hogarth and Kunreuther [1989]).

3 Joint and several liability was established as the standard that may be applied in hazardous waste cleanups under CERCLA by the court decision in U.S. v. Chem-Dyne (572 F. Supp. 802, 808).

Joint and several liability refers to a situation in which more than one party is found to have caused or contributed to certain, often indivisible, damages. "Joint" means that all such parties are together liable for all of the damages. "Several" means that each of such parties is liable for all the damages. Joint and several liability, then, means that a party entitled to a recovery can recover the entire amount of his damages from any one of the parties found to have caused or contributed, in some way, to the damages in question.

${ }_{4}^{4}$ Robert Ayers, et. al. v. Township of Jackson, (493 A. 2 d 1314 [1985]). 
In the case of environmental pollution insurance, the recent work of Henri Smets and the Organization for Economic Cooperation and Development (OECD) deserves mention. In a very complete analysis of environmental pollution damages in several areas (including air, noise, oil, transport and hazardous waste), Smets concludes from the available data for OECD countries that the frequency and severity of losses in these areas to date are well within the range of insurability in the sense that these empirical distributions are similar to those encountered for accidents such as airline crashes where insurability has not been a problem. (Smets, [1986]).

The key problem in the United States regarding environmental pollution lies in the hazardous waste area. Judicial decisions and legislative enactments have a major impact on escalating the uncertainties as to whether a claim will be filed and awarded. For example, the introduction of strict liability for cleanup of waste sites for all responsible parties, and the subsequent extension of joint and several liability to these cases, increases the likelihood that any party involved with the damage-causing waste site will be held partially liable.

\subsection{Moral hazard and adverse selection}

Both these conditions have an adverse impact on the provision of insurance. Moral hazard refers to intentionally careless behavior on the part of an insured, knowing that if an accident occurs it is covered by insurance. Adverse selection refers to the inability of the insurer to differentiate between good and poor risks because of imperfect information on the quality of the firm. If a premium is based on the average risk across all firms then the poor ones will purchase a disproportionate amount of coverage and the insurer will suffer unexpected losses.

One attempt by insurers to combat the problems of moral hazard, is the institution of the "owned property exclusion" clause in their contracts. In theory this ensured that the costs of maintaining a policyholder's property would not be borne by the insurer. However, in one recent case, the owned property exclusion was narrowed. ${ }^{5}$ The court held that the defendant insurer not only had a duty to defend and indemnify, it had a duty to abate further injury from improper waste disposal on the plaintiff's land. Since the insurance company was contractually obliged to pay for all past, present, and future damages for which the plaintiff might be found liable, and because the plaintiff in this case was unable to afford abatement measures, the court held that the insurance company must undertake to abate the hazard.

In another case,${ }^{6}$ the court overruled the defendant's contractual provisions regarding the pollution exclusion and owned property exclusion for removal of toxic waste from the plaintiff's property. It ruled that the insurer must cover these damages for reasons of public policy and held that "the health, safety and welfare of the people of this State must outweigh the express provisions of the insurance policy in issue".

Adverse selection can arise as a result of the retroactive imposition of liability as has occurred under CERCLA. All parties connected with the wastes disposed of at a particular

\footnotetext{
5 See Riehl, v. Travelers Insurance Company (Civil Action No. 83-0085 W. D. Pa., [1984]).

6 See Summit Associates, Inc. v. Liberty Mutual Fire Insurance Company, (No. L-47287-84, Superior Court of New Jersey, February 25, 1987).
} 
site have been held jointly and severally liable for the costs of cleanup. Thus those parties that have maintained accurate records of the wastes that they handled and have been covered by insurance would be listed as "potentially responsible parties", and held liable, while those who handled wastes but show no records of having done so might not be found liable.

\section{An insurability grid for hazardous waste problems}

The previous section outlined general conditions for insurability of environmental pollution liability coverage without distinguishing between the timing of events and the nature of the liability incurred. If one decomposes the problem then there are a set of risks that may be insurable. Table 1 presents a simple grid designed to determine what are insurable and uninsurable pollution risks.

Table 1

\begin{tabular}{c|l|l} 
& PAST & FUTURE \\
\hline $\begin{array}{c}\text { CLEANUP } \\
\text { Multi User }\end{array}$ & $\begin{array}{l}\text { Least } \\
\text { Insurable }\end{array}$ \\
\hline $\begin{array}{l}\text { Vertically } \\
\text { Integrated }\end{array}$ & $\begin{array}{l}\text { More } \\
\text { Insurable }\end{array}$ \\
\hline COMPENSATION & & \\
Multi User & & \\
\hline $\begin{array}{l}\text { Vertically } \\
\text { Integrated }\end{array}$ & More & Most \\
& Insurable & Insurable \\
\hline
\end{tabular}

The table distinguishes between past events, such as disposal of toxic materials in a landfill or accidents which have caused injury or environmental damage, and future events, such as planned disposal or potential accidental leakages of toxic materials during production, transportation, disposal or storage. It further distinguishes between the costs of cleanup of existing sites and the costs of settling suits for injury and/or damage. A further distinction is made according to policyholder characteristics. Multi user, refers to firms that share transportation and disposal facilities with other producers. Vertically integrated firms are those that handle waste disposal in house. 
The grid is meant to be illustrative rather than exhaustive. Certainly there are other dimensions that are of importance and there are environmental issues which do not fit comfortably in this grid. However, the grid is useful for highlighting insurability problems.

Liability for cleanup cost for existing multi-user sites comes within the top left cell of the grid. Insurability problems here are the most severe for reasons outlined in the previous section. Insurer involvement was envisaged under the CERCLA legislation. However, certainty associated with clean-up combined with the retroactive liability provision imply that the role for insurers was defined to be that of taxpayer rather than risk bearer.

The confiscatory nature of the tax arises since the insurers had no opportunity to price this into their premiums when the policies were originally issued. Such a tax may be enforced against insurers in two ways. The tax may be obtained by expropriation of shareholders' surplus. Alternatively, the tax may be raised by generating subsidies from other lines of their business, such as fire or automobile insurance, written by pollution liability insurers.

The scope for cross subsidies from other lines is limited by the knowledge and willingness of other policyholders to provide this subsidy. In a competitive insurance market, those insurers writing fire or auto business who were not encumbered by an existing pollution insurance portfolio would be able to underprice others who had to extract a subsidy from their fire or auto insurance lines to support the CERCLA imposed cleanup costs. In such circumstances, the EPA would effectively have no economic power to tax those other lines. This implies that the economic power to tax is limited by the extent of the policyholder surplus; beyond that point shareholders are protected by limited liability.

Current estimates of expected cleanup costs from designated "Superfund" sites is likely to far outstrip the aggregate surplus of all insurers who write general liability. (Katzman, [1988]). Given the severity of insurability problems in this cell it seems somewhat superfluous to distinguish between vertically integrated and multi user cases. Nevertheless, insurers of firms using multi user facilities have the aggravating problem that they may end up as the deep pockets should other users be untraceable, insolvent or uninsured. Thus for the top left cell of the grid the problems of insurability are excessively severe. Should the full potential for cleanup liability fall on existing insurers, the effect of future supply could be calamitous. Not only would such liabilities deplete existing capital (thereby affecting all lines) but investors would be extremely wary of future investments in the insurance sector lest future legislation impose some new confiscatory tax.

We will not go through all cells in the grid shown in Table 1. However, it is instructive to compare the top left cell, (cleanup costs for past losses), with the bottom right cell, (compensation for future events). In the bottom right cell, exposures create the least stress on the insurability conditions; problems, however, can still be serious. The uncertainty test for insurability is likely to be satisfied, but many other violations may arise. For example, judicial instability can still give rise to high correlations over time as future precedent-making cases redefine coverage on existing policies before they expire.

Insurers already have taken some steps to reduce this problem by developing contract forms such as "claims made" forms, that effectively reduce the time period over which policies are vulnerable to such changes. (Moreover, while some states have revoked joint 
and several liability (see GAO, [1987]) others still have this ruling). Vertically integrated facilities who would like to insure their future environmental risks are the firms most eligible for insurance. Trends indicate that many large, financially stable, and wellmanaged firms are moving in this direction with respect to waste disposal activities to avoid the problems associated with joint and several liability. Some underwriters have suggested to us that the accidental discharge from new, state-of-the-art, underground storage or incineration facilities, which are subject to intensive risk assessment and which are used only by their insured, could well be considered to be insurable. A limited amount of coverage is now written on future risks by several companies in the United States and in Europe.

\section{Role of insurance in an integrated waste management strategy}

Insurance is one of several policy instruments available for influencing economic, environmental and health consequences of risk management for hazardous wastes. In considering the role of insurance in an integrated risk management strategy, it is important to consider a few examples of how insurance influences decisions related to hazardous waste.

In the transport, treatment and disposal of hazardous wastes, insurance and financial responsibility requirements imposed by RCRA affect who will do business in these areas. Given the insurability problems arising from multiple party arrangements and the risks involved for small asset firms, it is difficult for anyone other than "high-tech" firms with considerable assets to obtain insurance in the hazardous waste area.

The financial consequences of liabilities arising from hazardous materials could be spread by insurance, enabling risky but economically beneficial production of goods with hazardous by-products. Insurance provides further social benefits by promoting the timely remediation of the consequences of environmental incidents involving hazardous wastes and in providing compensation to those suffering losses. Anticipation of the net liabilities remaining after insurance coverage and the desire to maintain continuing coverage with an insurer provide substantial incentives for firms to engage in proactive risk management, including the reduction of waste volume generated and transported and the development of safer methods of disposal.

The dictates of insurability and controllability of hazardous substances are complementary in promoting increased precision in classifying wastes, monitoring their movements and generating standards for hazardous waste equipment and facilities. Thus both insurers and responsible industry officials agree that a continuing strong commitment to health and safety regulations and standards is absolutely essential for both insurability reasons as well as for the monitoring and enforcement of regulatory policy.

The above points suggest a central role for insurance in managing hazardous wastes. Nonetheless, in discussing an integrated perspective, it is important to see insurers as only one of several interacting parties in the hazardous waste area. In Figure 1 below we show the interaction among interested parties, highlighting insurance decisions. Insurance conveys both information and incentives to waste generators, transporters and disposal operators. Depending on the nature of the insurance contract and the liabilities actually covered, ex-ante decisions (e. g., how much waste to generate or what transport technology 
to employ) and ex post consequences will be affected. As noted in previous sections, the features of insurance contracts and their interpretation by the courts also strongly affect the feasibility of having private insurers and industry agree to an insurance contract in the first place.

Figure I

Conceptual framework for analyzing insurability problem

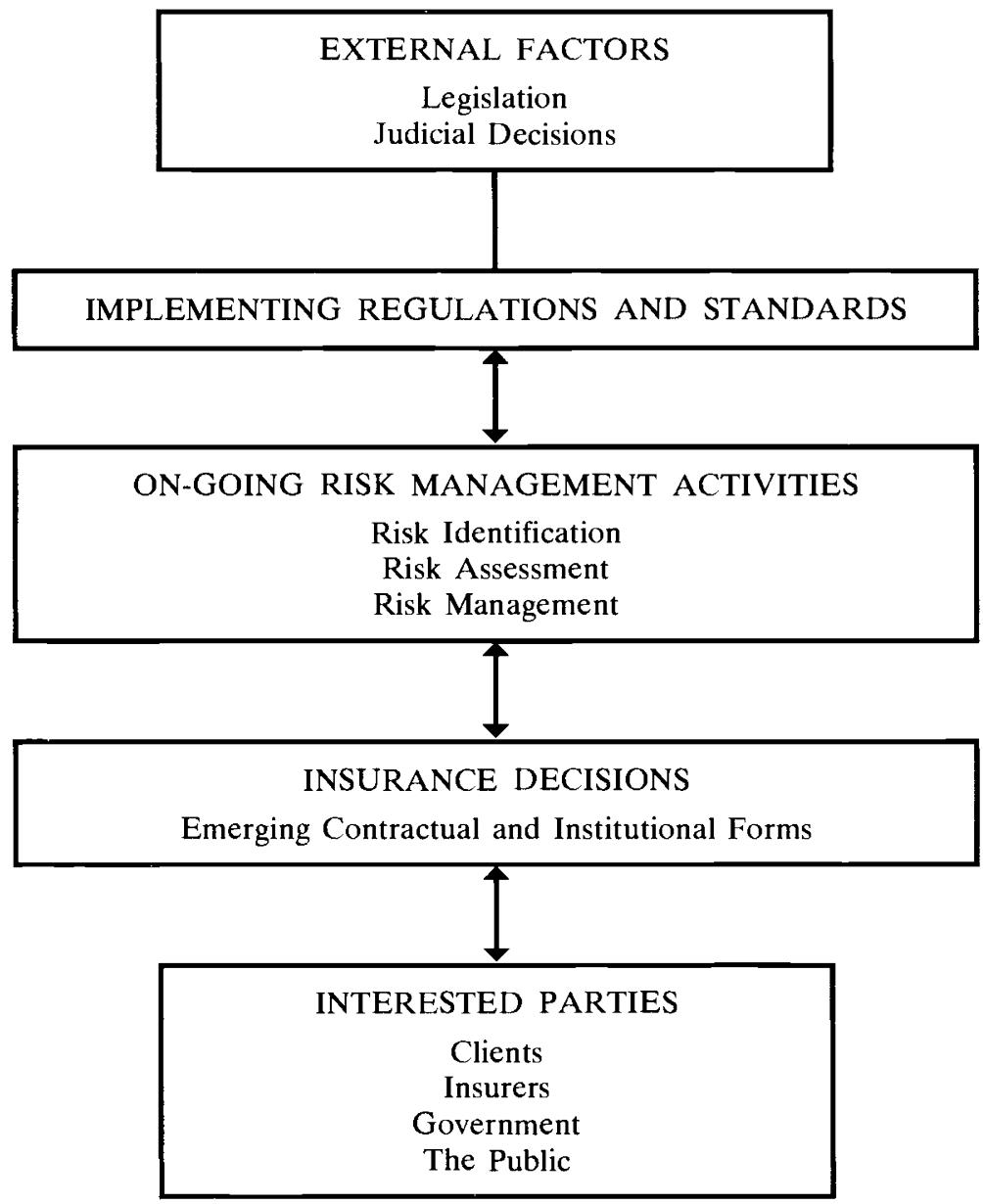

The availability and price of insurance will interact with firm characteristics and policy constraints in the choice by firms of risk management alternatives undertaken by firms. And these choices will determine the environmental, health and economic consequences 
of risk management activities. Several specific areas of hazardous activity have been analyzed by determining the effects of insurance requirements and various liability rules on risks to exposed individuals and society under the assumption that an industrial firm minimizes its expected costs:

The reduction of hazardous waste flows (Kleindorfer [1986]);

Transport decisions related to hazardous waste (Kleindorfer and Vetschera [1987]);

Site remediation decisions for treatment and disposal facilities (Kleindorfer and Kunreuther [1987]).

In each case, several general features arise from the analysis.

5.1. Private and social costs often diverge in the sense that what is best for firms may not be best for society. This leads to various second-best tradeoffs in regulating hazardous risks and in setting insurance requirements. The nature of these tradeoffs is significantly affected by the level of assets at risk by the firm (the higher the level of assets, the stronger the incentives for risk reduction) and by the nature of the liability rules in force (see Shavell [1987]).

5.2. Insurance coverage, residual liability and the level of protective activity are joint decisions by firms and insurers and must by analyzed jointly to understand their financial and other (e.g., environmental) effects.

5.3. Social equity in risk bearing and the efficiency and scope of victims compensation also are strongly related to insurance and liability requirements.

Insurance has a central, but mediating, role in the risk management process. On the one hand, insurance assures compensation for damages should they arise. On the other hand, insurance provides incentives to risk managers of firms through premium differentiation and coverage availability for potential liabilities. When confronted with these incentives risk managers can and will make corresponding decisions.

Competitively available insurance may be viewed simply as a part of the normal cost of producing the goods whose by-products are the hazardous wastes in question. The operations themselves must, of course, be compatible with established standards and regulations embodying considered social judgments on the appropriate tradeoff between cost (including insurance cost), environmental and health consequences. This view of insurance implies that its integration into risk management and operations is no different than that for other factors of productive activity. In this sense, the most important problem in resolving an appropriate role for insurance in an integrated risk management strategy for hazardous wastes is to establish conditions under which a competitive market for EIL insurance can be assured. Therefore, we turn our attention now to appropriate measures which might move us from the present very thin market for EIL insurance to a more stable and viable setting.

\section{Expanding the environmental insurance market}

The principal benefit of industry's failure to obtain pollution insurance is that many firms are now cleaning up their act. Chemical companies have been modifying their production processes so as to reduce the amount of toxic wastes to be disposed. In addition, they are relying on cleaner means of dealing with their wastes through incineration. Yet 
with the exception of the very largest industrial firms, most companies have a need for pollution insurance. In this section we will outline a strategy for helping to restore the environmental pollution insurance market.

As we discussed in the previous section, strict standards and careful monitoring procedures are essential if insurance is to be used as a policy tool in developing a meaningful hazardous waste strategy. But changes are needed if insurance is to emerge as a meaningful policy tool in hazardous waste management:

\subsection{Changes in contract design}

Given the rapid and retroactive evolution of liability rules, it is inevitable that insurers have sought to redesign their contracts in order to insulate themselves from new undiversifiable and unpriceable risks. The obvious example of such a change is the substitution of the "claim made" contract for the "occurrence" policy. The old policies gave the policyholder protection both for his personal or idiosyncratic risk assessed against a given set of liability rules, but, in effect, also against the common risk of changes in the rules themselves. The idiosyncratic risk is diversifiable and is the type of risk for which insurance is intended. But the risk associated with changing liability rules is not amenable to the insurance process.

The "claims made" policy gives some protection to insurers from assuming the second type of risk. The essential difference between the two types of contracts is that the insurer can defer its underwriting and pricing decisions for "latent" claims, i.e. those that are not discovered and filed till after the policy period.

Attempts to introduce the claims made policy form for general liability cover have had a chequered history amongst state insurance commissioners. While much commercial liability insurance and, to our knowledge, all EIL cover currently sold, is on a claims made basis, some states have resisted this concept as a degradation of cover.

It is true that the claims made policy passes some of the risk of changing liability rules back to the policyholder thus forcing him to "coinsure". On the other hand, the prospect of insuring undiversifiable risk under the occurrence policy, forces the insurer, if it were to offer coverage, to load its premiums severely to protect its financial stability (and thereby offer its policyholders a reasonable expectation that their claims will be honored). This loading of the premium will itself deter insurance purchase and force the policyholder to coinsure or self insure.

At least by decomposing risk into that which is diversifiable and that which is not, the claims made policy achieves a more rational sharing of risk between policyholder and insurer (see Doherty [1987]). This reasoning leads to the conclusion that the revival of the insurance market will proceed more smoothly if policyholders and insurers are left to negotiate contracts which offer mutual gains from trade.

\subsection{The enforceability of insurance contracts}

The willingness of insurers and policyholders to negotiate contracts that offer mutual gains from trade depends also on their expectation that the contracts will be enforced as written. The history of the difficulties in the pollution insurance market is one in which insurers have complained that the courts have found cover in circumstances in which the intention to provide cover was not present at the time the contract was written nor could any reasonable interpretation of the contract conditions support such settlements. Of 
course, it is the prerogative of courts to interpret contracts and resolve disputes. Nor do three academics have any comparative advantage over courts in imposing reasonable interpretations of contract wordings. Thus we are not in position to evaluate decisions such as that of Jackson Township described earlier.

But the issue here is not whether particular court interpretations are reasonable or correct but whether they convey to parties engaged in the writings of future contracts an expectation that those contracts will be enforced as written. Both the words and the actions of the insurance industry (their protests and their widespread withdrawal from the EIL market) testify that the courts have been unable collectively to fulfil this expectation. In their efforts to extract compensation from insurers, the courts may well have killed the goose that laid the golden egg!

Interpretation of policy wordings is one problem, the apparent disregard of those wordings to pursue social objectives is another. The Summit Associates case mentioned earlier may well turn out to be an anomaly. But if the precedent set by this case turns out to be robust, the consequences for the revival of a voluntary insurance market are bleak (see Cheek [1990]). The issue of concern in this case rests on a policy wording that excluded liability under the policy for damage to property owned by the policyholder. In overriding this exclusion, the court stated:

The underlying Public Policy in this case is quite clear when the potential for damage to the environment is this great. Consequently, the health, safety and welfare of the people of this State must outweigh the express provisions of the insurance policy in issue. As a result, the exclusion clause in the policy which pertains to excluding coverage where the damage is to the policyholders land, must be held inapplicable where the danger to the environment is extreme.

The issue seems to be that, by the very fact of issuing a policy, the insurer becomes liable to finance public policies, as determined by future courts. Such a liability is in the nature of a tax since the insurer can only reasonably price its contracts on the basis of the cover it offers and which is affirmed in the contract provisions.

\subsection{Changes in organizational form}

As indicated above, traditional designs of insurance contracts may not be optimal for the environmental pollution market. It may also be the case that traditional insurance organizational forms may be ill suited to this market. The superiority of the "claims made" policy over the "occurrence" policy lay in its facility for decomposing risk into that which is diversifiable and that which is not.

Another method for achieving the same ends is the mutualization of insurance. In a mutual, or any other pool that is collectively owned by its policyholders, the functions of policyholders and shareholders are combined. This implies that risk which is not diversifiable within the pool is passed back to the owners of the pool, (i.e. the policyholders), in the form of a risky dividend. Thus, in the absence of reinsurance, diversifiable risk is spread amongst members of the pool, but undiversifiable risk is retained by the policyholders. A reinsurance contract for covering this undiversifiable risk (which may lead to unusually large losses) should effectively decompose the risk. The fact that undiversifiable risk will command a risk premium affects only the amount of reinsurance purchased and not the integrity of the pool (see Doherty and Dionne [1987]). 
Given these advantages to pooling, it is not surprising that several pools have recently been started to cover gradual pollution losses. To date none have thrived. There is a good reason for this: the problem of adverse selection. Each company contemplating joining the pool is concerned that the other members will be more likely to have an accident than they will. If you feel you are the safest company on the block then there is no interest on your part in having others join you. An obvious solution in theory would be to have on-site inspections at the outset to determine relative risk and careful monitoring procedures after the pool was established. Rates would then be based on how safe the plant is considered relative to others. In practice it is not easy to rank companies on the safety and risk dimension since each firm is unique.

\subsection{Integrating a Scheduled Compensation System with the Tort System}

Nicholas Ashford and his co-authors [1987] suggest the setting up of an administrative scheduled compensation system which will function in conjunction with the tort system. Once the exposure to toxic substances is discovered, a potential victim may apply to the administrative system for interim measures of support for medical surveillance and rehabilitation. The funds to support these payouts could come from a combination of feed-stock taxes, waste-end taxes and insurance premiums for victims' compensation.

In the event that no responsible party capable of paying the losses can be discovered, the victim will be paid out of the administrative system according to a multi tiered schedule of awards. In the event that an insured or defendant is identifiable, the victim can, by his own choice, proceed through the victims' compensation system or through the tort system. If the victim chooses to take the administrative route, payments would proceed according to the predetermined schedule. Immediate payment for the victim, with subrogation of the fund against the insured, could be a part of this scheme. The principal advantage of the administrative system is that it sets up a schedule of damage awards with immediate payment as against the open-ended awards that would arise under the tort system.

This proposed system may pave the way for the reintroduction of pollution liability coverage since insurance companies could now offer coverage for claims filed under the administrative system even if they determined that coverage under the tort system settlements was still uninsurable.

\section{A proposal for insuring hazardous waste}

To conclude this paper we will develop the features of a program where insurance is an integral part of a hazardous waste management strategy. We recognize that there is a tension between the role that both the legislative and judicial system would like insurance to play in encouraging risk-reduction by industry and the insurability criteria that influence what type of coverage the insurance industry is actually willing to offer.

The objective of an insurance program for hazardous waste would be to encourage producers, transporters and storers of this waste to reduce the potential damage to the environment while at the same time providing a source of protection to such parties and compensation to the potential victims. In developing such a system we need to recognize explicitly three features of the pollution problem today which require some type of privategovernmental combination in providing insurance protection: 
Feature 1: There is considerable uncertainty and ambiguity regarding the probability that specific events (e.g. leakage from a landfill) will cause specific diseases to individuals. Hence standard actuarial techniques cannot be used by the insurance industry in setting rates.

Feature 2: Current tort law does not define explicitly the precise nature of the liabilities to be borne by different interested parties involved in environmental pollution cases. Concepts such as retroactive liability and joint and several liability have created considerable uncertainty in this regard.

Feature 3: Liability rules have been unstable. Major changes in liability rules have arisen both through legislative changes and through the setting of precedents in civil cases. Moreover such changes often arise between the time a policy is written and the ultimate discharge of all claims under that policy. Insurers cannot effectively price this risk.

With these three features in mind, what type of viable insurance program will encourage manufacturing industry to reduce the risk associated with hazardous waste and provide adequate compensation to potential victims? Figure 2 depicts the different layers

Figure 2: Insurance Markets and Layers of Coverage

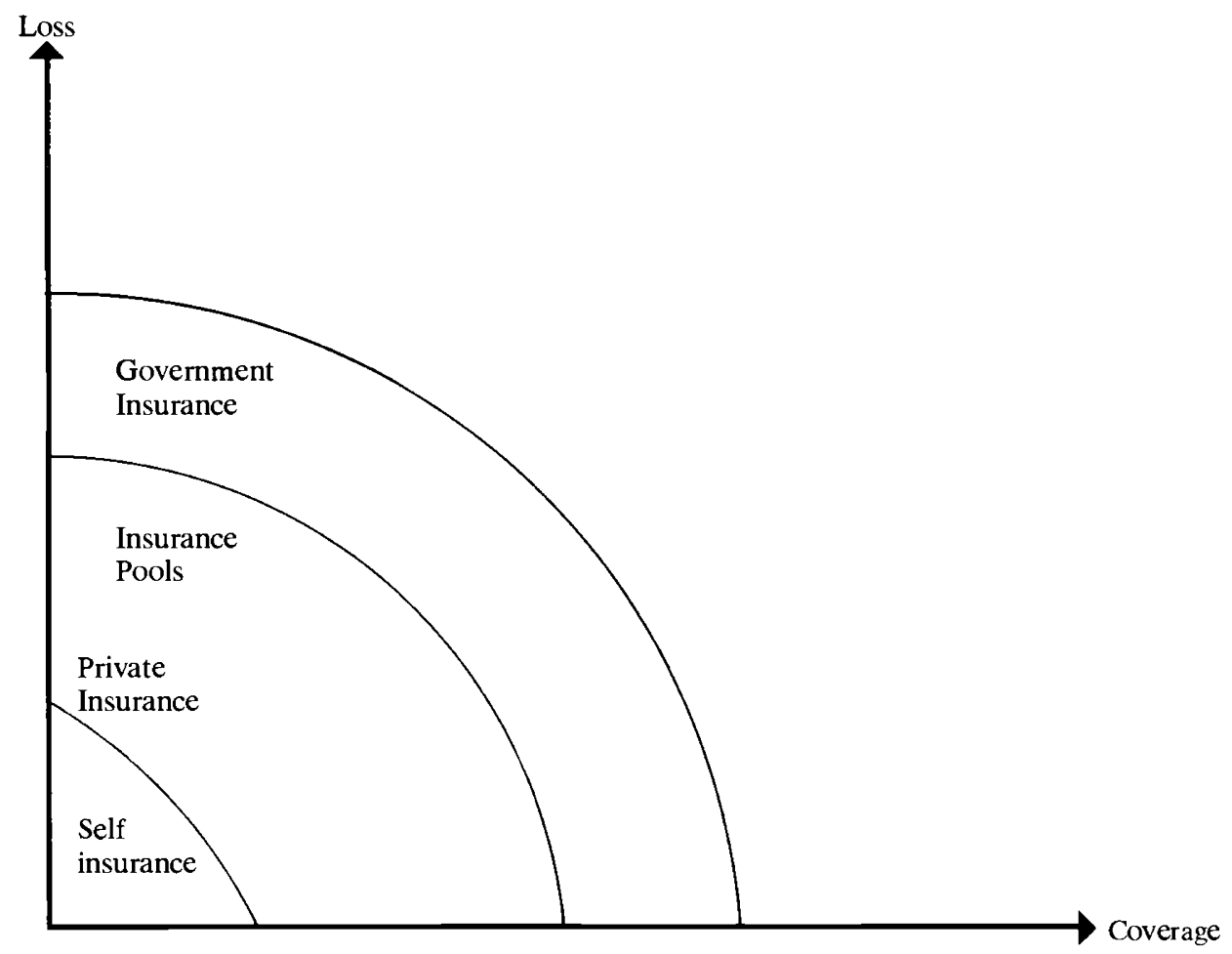


of coverage that can be provided against losses of different magnitudes by a well-specified risk-sharing arrangement between industry, insurers and the government. Taken together this three layer program appears to be a useful starting point for combining insurance with other features of an integrated hazardous waste management program.

Layer 1: Self Insurance: In order to encourage industry to adopt safer production and disposal practices they must be required to bear the first level of pollution losses. This is equivalent to having a deductible on an insurance policy. There is an incentive for an industrial firm to consider safer production techniques if it knows that by so doing it can reduce the potential losses it will have to bear itself.

Layer 2: Private Insurance or Insurance Pools: Private insurers should be willing to provide standard coverage against the next layer of losses as long as there is a well-specified upper limit that will not be challenged in court. By using risk-assessment techniques for appraising an industrial firm's operation, premiums for this layer of coverage can reflect the relative magnitude of risks. Today only two or three insurance firms have been utilizing such an approach in marketing coverage. We see these formal risk assessments as becoming standard practice in the future. As long as the upper limit of liability is welldefined then insurers should be willing to offer environmental pollution coverage for this layer.

As a substitute for insurance provided by a conventional insurance carrier, layer 2 could be provided by an industrial pool, or group captive insurance arrangement. Under such an arrangement, a group of firms simply pool their pollution exposures. Each firm is simultaneously a "policyholder" and a shareholder of the pool. The coverage afforded by the pool will lie within a well-specified band (e.g. between $\$ 20$ million and $\$ 50$ million) and the pool will often be set up and managed by an insurance broker. The advantages of such a pool are obvious: a number of firms are contributing so that if one of them is unlucky it will be protected. It is not necessary to estimate explicitly the probability of losses of different magnitudes except to provide guidelines as to the size of the contributions by each firm. The pool is not designed to make a profit but rather to have sufficient resources to cover losses in the future. The principal difficulty in forming such a pool is the concern by every firm that enters that they will be the safest one on the block. Hence the importance of risk assessment procedures to delineate differences between safe and not-so-safe firms and the importance of using deductibles and other risk-sharing arrangements (e.g. coinsurance) for encouraging each firm to be concerned with future risks without relying on extensive monitoring and control procedures.

To date insurance pools have not been successful in the environmental pollution area although attempts have been made by several large insurance brokers. We are more optimistic regarding their formation in a system such as the one we are proposing since the upper limits of coverage are well-defined. There may thus be little need for any type of reinsurance arrangement for the pool, a source of funds that has dried up for pollution coverage during the recent insurance crisis. A sign of encouragement is the recent success of the ACE program, an insurance pool developed in 1986 by Marsh and McLennan for covering losses from general liability. It has a large deductible $\$ 100$ million and a wellspecified layer of coverage (losses between $\$ 100$ and $\$ 200$ million) so that a very select group of firms will want to join. The lessons from ACE might be applied to the more difficult problem of forming an industrial pool with a lower layer of coverage for environmental pollution. 
Layer 3: Goverment Involvement. Given the current status of legislative rulings on hazardous waste as well as current tort law, it appears to us both essential and appropriate to turn to the government for the last layer of coverage. The uncertainty in the magnitude of the potential losses makes it highly unattractive for insurers to provide pollution coverage except on a highly selective basis. Private reinsurers are reluctant to provide excess loss coverage given recent toxic tort settlements in this area. Hence some form of government reinsurance for losses above a certain magnitude may be an essential element of any large-scale insurance program for managing hazardous waste.

We propose that a governmental agency similar to the Federal Insurance Administration be responsible for levying a fee on industrial firms to cover the potentially large losses which exceed the limits of layer 2 . This fee would be partially based on the degree of risk faced by the particular firm (as determined by risk assessment procedures) as well as the desired and/or required levels of coverage by the firm. Such a system has several advantages over private sector reinsurance arrangements. There is less need for the government to be as concerned with developing actuarially sound premiums since the principal objective of having them assume this layer of coverage is to provide compensation to victims rather than making a profit. The incentives for encouraging risk reduction measures by industry lie in the first two layers of coverage. It also seems appropriate for government to handle large liability losses since they are the party principally responsible for the current state of affairs through CERCLA and RCRA legislation. Government also can have an impact on judicial reform (if that is deemed appropriate) in a much more direct manner than either industrial firms of the insurance industry.

By having the government directly involved in an insurance program it has the opportunity to wield a big stick in facilitating an integrated waste management strategy. It can impose regulations and standards on industrial firms in return for providing Layer 3 protection to them. It can also coordinate and help centralize a data base on losses and actual claims from pollution policies and thus help provide data for rate setting across Layers 2 and 3 . Finally the government will be directly involved in providing compensation to victims rather than having such payments come indirectly through general tax funds.

On the other side of the ledger is the potential danger that government involvement in this final layer of coverage against losses will open up a Pandora's box in a fashion similar to workman's compensation. The principal hedge against this moral hazard problem is the presence of the other layers of coverage, all of which explicitly encourage industry to operate safer facilities and reduce their side-production of hazardous waste.

In summary, we see insurance as a vital part of a program on managing hazardous waste but feel that industry, insurers and the government have to join forces to make it work. Future legislation such as the renewal of Superfund in 1991 and reform of the current tort system will shape the relevant roles of each of these parties. However, we feel that even if there are radical changes in the legislative and judicial rulings there will be a need for all three parties to each play a key role in the development of an insurance program that meets both societal objectives as well as conditions of insurability. 


\section{Appendix A}

Insurability criteria and environmental pollution: A scenario

The following hypothetical scenario motivates a discussion of insurability issues as these relate to environmental pollution:

Two industrial concerns, the Alpha Chemical Company and the Beta Paint Company, dispose of their toxic wastes at the Wellbent Waste Management Inc.'s landfill. This is a state-of-the-art landfill which is lined with polyethylene and covered with a thin layer of clay and sited in a large trench. There is still a low probability of groundwater leachate which can contaminate the municipal water supply of the neighbouring town of Voxpopuli.

Alpha would like to purchase insurance coverage against liability for environmental pollution from the Cappa Insurance Company. Cappa knows that Beta is uninsured and has been studying whether it should provide coverage to Alpha. In fact, Cappa has been seriously investigating whether or not to provide this type of pollution coverage to other industrial firms as well. What action should it take?

The decision by Cappa as to whether it wishes to provide insurance coverage to Alpha and other firms will be determined to a large extent by the nature of the environmental risk. The criteria for insurability that we have laid out will now be examined in the environmental pollution liability context.

\section{Uncertainty}

Cappa is unlikely to provide insurance to Alpha because this criterion is not satisfied. Its insurance policy limits cover events that are unintended and uncertain. Thus they exclude coverage for all pollution incidents that are not "sudden and accidental". The courts have interpreted the phrase "sudden and accidental" to cover gradual pollution incidents, stating that the damages which occurred were "unintended and unexpected" from the standpoint of the insured.

\section{Low correlation}

Environmental risks are not highly correlated at one point in time. However, the effects of legal developments and judicial interpretations are felt across the system and affect all insurance contracts. For example, the introduction of joint and several liability by courts in their interpretation of CERCLA, introduces a new liability retroactively for all companies involved in the various stages of the waste lifecycle.

The Cappa Insurance Company, in attempting to draw up a contract to cover Alpha Chemical, may be reluctant to do so because it fears that judicial and legislative changes would make all the companies in its pool suddenly liable for unanticipated damage.

\section{Identification of losses}

Problems of identifiability for environmental risks are well-known. First, the long latency periods for the development and recognition of damages are clear. A landfill may leach for many years before identifiable effects are noticed. If the firm liable for the landfill had several insurers during this period, severe identification problems arise.

Second, court decisions have clouded the issue of identifiability of losses. For example, courts have redefined the meaning of the term "occurrence". In the now famous Jackson 
Township case, the court decided that the contamination of 97 wells resulted in 97 different pollution occurrences and proceeded to apply the coverage accordingly.

Third, in the Jackson Township case the court went on to award damages for nonpecuniary losses. A total of $\$ 15.9$ million (reduced on appeal to $\$ 5.4$ million) was awarded for emotional distress, impact on quality of life, and cost of medical surveillance, to the plaintiffs who were victims of pollution.

Such drastic interpretations could make the coverage offered by Cappa Insurance to Alpha Chemical somewhat different from that previously envisaged. In particular, nonmonetary damages cannot be covered by insurers because they are not amenable to clear identification.

\section{Estimating the probability of loss}

Regarding the estimability of loss probabilities in the case of environmental pollution insurance, judicial decisions and legislative enactments have had a major impact on escalating the uncertainties as to whether a claim will be filed and awarded. For example, the introduction of strict liability for cleanup of waste sites for all responsible parties, and the subsequent extension of joint and several liability to these cases, increases the likelihood that any party involved with the damage-causing waste site will be held partially liable.

For this reason Cappa Insurance is wary of providing coverage readily to Alpha Chemical, even if the basic probability distribution can be estimated.

\section{Moral hazard and Adverse Selection}

These problems dog the environmental pollution liability area and insurers have come up with various schemes to tackle them. Moral hazard refers to intentionally careless behavior on the part of an insured, knowing that if an accident occurs it is covered by insurance. Adverse selection refers to the inability of the insurer to differentiate between good and poor risks because of imperfect information on the quality of the firm. If a premium is based on the average risk across all firms then the poor ones will purchase a disproportionate amount of coverage and the insurer will suffer unexpected losses.

In our hypothetical example, the difficulty in monitoring Wellbent Waste Management's landfill over time presents Cappa Insurance with a moral hazard problem once it issues insurance to Alpha Chemical. If Alpha were utilizing the landfill alone, then it would be possible to reduce such problems by instituting coinsurance and deductibles as part of the insurance policy. With Beta, an uninsured party sharing the landfill, there is little that can be done to prevent this other firm from being careless in disposing of their waste, as it knows that any damages caused would be handled by the insurance coverage obtained by Alpha.

The problem of adverse selection also arises in this case. Trends indicate that many large, financially stable, and well managed firms are moving towards the vertical integration of waste disposal activities to avoid the problems associated with joint and several liability. Such firms may well be capable of insuring themselves. This might mean that the only clients seeking the insurance coverage offered by Cappa Insurance are those that would be high risks. 


\section{REFERENCES}

ABRAHAM, K. (1982), "Cost Internalization, Insurance, and Toxic Tort Compensation Funds", Virginia Journal of Natural Resources Law, Vol. 2.

All Industry Research Advisory Council, (1985), Pollution Liability: The Evolution of a Difficult Insurance Market.

ASHFORD, N. A., MORAN, S. and STONE, R. F. (1987), The Role of Changes in Statutory/Tort Law and Liability Insurance in Preventing and Compensating Damages from Future Releases of Hazardous Waste, Center for Technology, Policy, and Industrial Development, Massachussetts Institute of Technology, Cambridge, MA.

BERLINER, B. (1982), Limits of Insurability of Risks, Prentice-Hall, Englewood Cliffs, NJ.

CHEEK, L. III (1982), "Risk-spreaders or Risk-eliminators? An Insurer's Perspective on the Liability and Financial Responsibility Requirements of RCRA and CERCLA", Virginia Journal of Natural Resources Law, Vol. 2.

CHEEK, L. (1990), "Insurability Issues Associated with Cleaning Up Inactive Hazardous Waste Sites".

DOHERTY, N. A. (1987), "Insurance with Random Premiums", Working Paper, University of Pennsylvania.

DOHERTY, N. A. and DIONNE, G. (1987), "Insurance with Undiversifiable Risk", Working Paper, Center for Research in Risk and Insurance, University of Pennsylvania.

HOGARTH, R. and KUNREUTHER, H. (1989), "Risk, Ambiguity, and Insurance", Journal of Risk and Uncertainty (forthcoming).

KATZMAN, M. T. (1988), "Pollution Liability Insurance and Catastrophic Environmental Risk", Journal of Risk and Insurance, Vol. 55.

KLEINDORFER, P. R. (1986), "Environmental Liability Insurance: Perspectives on the U. S. Insurance Crisis", Working Paper, Risk and Decision Processes Center, University of Pennsylvania.

KLEINDORFER, P. R. and KUNREUTHER, H. (eds.) (1987), Insuring and Managing Hazardous Risks: From Seveso to Bhopal and Beyond, Springer Verlag, Berlin and New York.

KLEINDORFER, P. R. and VETSCHERA, R. (1987), "Risk-Cost Analysis Model for the Transportation of Hazardous Substances", Working Paper, Risk and Decision Processes Center, University of Pennsylvania.

KUNREUTHER, H. (1987), "Problems and Issues of Environmental Liability Insurance", The Geneva Papers on Risk and Insurance, Vol. 12.

KUNREUTHER, H. and GOWDA, R., "Integrating Insurance and Risk Management for Hazardous Wastes" (Boston: Kluwer).

SHAVELL, S. (1987), Economic Analysis of Accident Law, Harvard University Press, Cambridge, MA.

SMETS, H. (1987), "Compensation for Exceptional Environmental Damage Caused by Industrial Activities", in Kleindorfer and Kunreuther (eds.) Insuring and Managing Hazardous Risks: From Seveso to Bhopal and Beyond, Springer Verlag, Berlin and New York.

United States General Accounting Office (1987), Hazardous Waste: Issues Surrounding Insurance Availability, Washington D.C. 